Egyptian Journal of Aquatic Biology \& Fisheries

Zoology Department, Faculty of Science,

Ain Shams University, Cairo, Egypt.

ISSN $1110-6131$

Vol. 24(7): 955- 972 (2020)

www.ejabf.journals.ekb.eg

\title{
Comparative study on morphometric relationships and condition factor of Siganus rivulatus inhabits the Red Sea, Suez Canal and the Mediterranean Sea, Egypt
}

\author{
Elham M. Abdelhak ${ }^{1, *}$, Azza A. El Ganainy ${ }^{2}$, Fedekar F. Madkour ${ }^{1}$, \\ Mohamed A. Abu El-Regal ${ }^{1 \& 3}$, Mohamed I. Ahmed ${ }^{4}$
}

1. Department of Marine Science, Faculty of Science, Port-Said University, Egypt.

2. National Institute of Oceanography and Fisheries, Suez, Egypt.

3. Marine Biology Department, Faculty of Marine Science, King Abdul-Aziz University-80207, Jeddah, Kingdom of Saudi Arabia. (present address)

4. Department of Marine Science, Faculty of Science, Suez Canal University, Egypt.

*Corresponding author: elham.aqua@yahoo.com

\section{ARTICLE INFO}

Article History:

Received: Nov. 12, 2020

Accepted: Dec. 9, 2020

Online: Dec. 21, 2020

\section{Keywords:}

Lessepsian migration,

Siganus rivulatus,

Morphometry,

Length-weight

relationship,

Condition factor,

Red Sea,

Suez Canal,

Mediterranean Sea.

\section{ABSTRACT}

Siganus rivulatus is one of the most successful Lessipsian migrant fish from the Red Sea to the Mediterranean Sea through Suez Canal. In the present study, a comparison between the populations in native and new habitats was estimated based on morphometric characters, meristic count, and condition of the fish. A total of 1741 individuals of $S$. rivulatus (334 from the Red Sea; Hurghada, 581 from Suez Canal; Ismailia and 826 from the Mediterranean; Port-Said) were collected seasonally from autumn 2017 to summer 2018. The total length (TL) fluctuated between $14-28 \mathrm{~cm}$ in the Red Sea with the mode at length-class $16-16.9 \mathrm{~cm}(14.37 \%)$, while TL in Suez Canal and the Mediterranean ranged from 8 to $22 \mathrm{~cm}$, the mode was $10-10.9 \mathrm{~cm}(25.3 \%)$ and $12-12.9 \mathrm{~cm}(15.25 \%)$, respectively. TL, SL and TW displayed significant differences between sites (ANOVA, $P \geq 0.05$ ), with the higher values of all morphometric parameters for Red Sea population. The meristic equation was "D, XIV+10; A, VII+9; V, I+3+I; P, 15-16" at all studied sites. Length-weight relationships were estimated as $\mathrm{W}=0.0112 \mathrm{~L}^{3.0349}, \quad \mathrm{~W}=0.0085 \mathrm{~L}^{3.1825}$, and $\mathrm{W}=0.0154 \mathrm{~L}^{2.9091}$ for the Red Sea, Suez Canal and the Mediterranean, respectively. Seasonal variation in Fulton's condition factor $(\mathrm{Kf})$ and Clark's $(\mathrm{Kc})$ were estimated based on the total weight (TW) and gutted weight (GW) respectively. The values of $\mathrm{Kf}$ and $\mathrm{Kc}$ showed significant differences between sites (ANOVA, $P \geq 0.05$ ). Kf seemed to be affected by temperature as the maximum value recorded in summer while the minimum was in winter. was considered another factor that may affect the condition of the fish as spring (reproductive season) showed high decrease in the value of $\mathrm{Kc}$ at all sites when we removed the mature gonad.

\section{INTRODUCTION}

Rabbitfish (Family Siganidae) is a widespread fish especially in the Indo-Pacific region (Woodland, 1983) that considered from the most popular fish food in many parts of the world (Lam, 1974). They are represented by four species in the Egyptian sector of the Red Sea; Siganus rivulatus, S. luridus, S. argenteus and S. stellatus (Fischer \& Bianchi, 1984). The opening of Suez Canal in 1869 allowed the migration of several Red Sea species to the 
Mediterranean Sea which known as the Lessepsian migrant species (Por, 1978). The two species; S. rivulatus (Forsskål, 1775) and S. luridus (Ruppel, 1828) are the most successful Lessepsian migrant fish via the Suez Canal which established in the Mediterranean Sea with a large population (George et al., 1964; Aleem, 1969; Ben-Tuvia, 1978, 1985; Papaconstantinou, 1990; Bariche et al., 2004). The marbled spinefoot rabbitfish, S. rivulatus, which known locally as "Sigan" is the most common which established in the Mediterranean Sea constituting high economic importance (Aleem, 1969; George, 1972; Papaconstantinou, 1990). According to GAFRD (2016), the average rabbit fish Egyptian catch, mainly Siganus rivulatus, was 500 tons from the Red Sea and 828 tons from the Mediterranean during 2018.

The relationship between length-weight can be used to determine the well-being of individuals and the differences between the same species at different locations (King, 2007). It also important in fisheries management for growth studies among species (Moutopoulos \& Stergiou, 2002). Condition factor " $K$ " is another expression and approach for dealing with the length- weight studies indicates the suitability of a specific water environment for growth of fish by comparing the value for a specific locality with that of another (Alam et al., 2014). It is used also to express fish condition with regard to degree of wellbeing, fatness or relative robustness in numerical terms (Schneider $\boldsymbol{e t}$ al., 2000) and considered a measure of various ecological and biological factors. The "K" values depend generally on physiological features of fish especially maturity, spawning, life-cycle, environmental factors and food availability in a water body (Ujjania et al., 2012; Dan-Kishiya, 2013).

Due to the growing of needs to fish protein and the increasing importance of $S$. rivulatus in Egypt, more researches are needed for a better management policy to preserve good population structure and its sustainable future in the Egypt especially after observation of decreasing in its catch in the last four years (GAFRD, 2018).

Some biological and ecological studies on $S$. rivulatus have been conducted in different Egyptian coasts (El-Gammal, 1988; El-Ganainy \& Ahmed, 2002; in the Red Sea, ElDrawany, 2015 in Bitter Lakes, and El-Okda, 1998; El-Far, 2008 in the Mediterranean). Abdelhak et al. (2020) studied the reproductive biology of this species from the Mediterranean and Red Seas and Suez Canal. Siganus rivulatus population in the Mediterranean Sea are morphometrically and genetically similar those population that relate to coral reefs in the Red Sea (Mohammed, 1991; Hassan et al., 2003), in spite of the few morphological changes noted between the two habitats (Diamant, 1989; Golani, 1990).

The aim of the present study is to compare the morphometric relationships such as lengthweight relationship and condition factor of S. rivulatus inhabit in their native habitat (Red Sea), and those established in new habitats (Suez Canal and Mediterranean Sea). The updating of basic biological information of $S$. rivulatus is needed for the evaluation of the status of the fish to implement the best planning of its fishing and culturing in the Egyptian waters and manage its sustainability.

\section{MATERIALS AND METHODS}

- Sampling and study area

A total of 1741 specimens of Siganus rivulatus were collected from the Red Sea at Hurghada (334), Suez Canal at Ismailia (581) and the Mediterranean Sea at Port-Said (826) (Fig. 1). Samples were obtained seasonally during the period autumn 2017- summer 2018 from the 
artisanal fleet working at these areas. Fishes were put in crushed ice and transported to the laboratory immediately for further analysis.

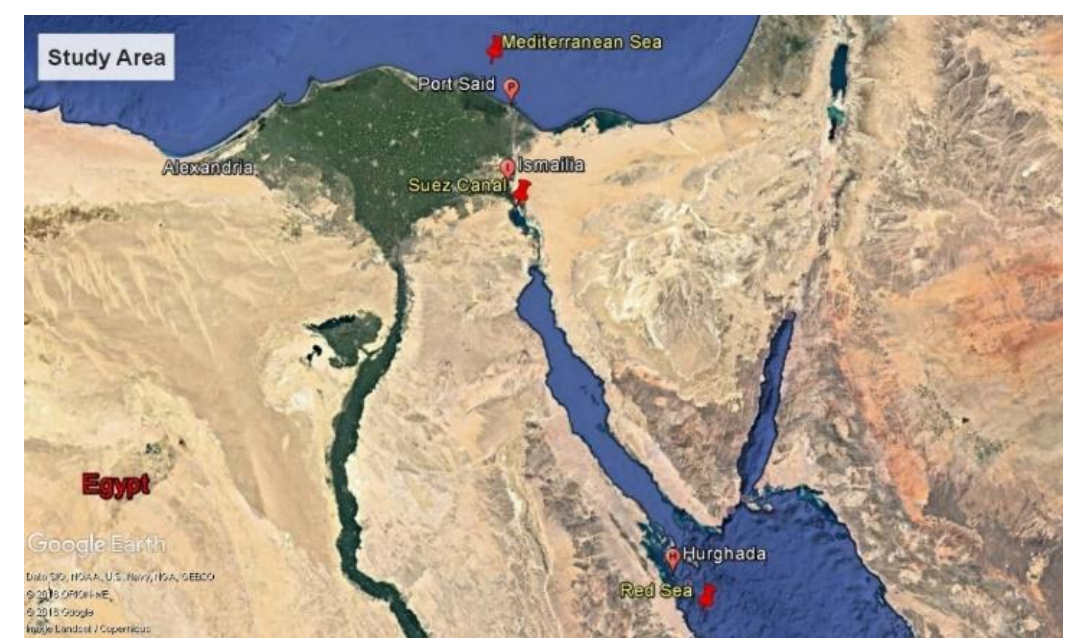

Fig (1): Location of the three studied sites; Red Sea (Hurghada), Suez Canal (Ismailia) and Mediterranean Sea (Port Said).

\section{- Meristic and morphometrics parameters and relationships}

Different morphometric measurements; total length (TL), standard length (SL), width, head length (HL), pre dorsal length (PDL), pre anal length (PAL), orbit length (O) -Eye diameter- the length between the anterior and posterior margins of the eye, and inter-orbital width (IO) that length between the edges of the two eyes which measured from the ventral side (Fig. 2), were measured according to Froese \& Pauly (2004) for each fresh specimen to the nearest $0.1 \mathrm{~cm}$. Total weight (TW) and Gutted weight (GW) -body without viscera; stomach and gonad- were weighed with an accuracy of $0.1 \mathrm{~g}$.

Relations between total length and the different morphometric parameters (TL against each of SL, width, HD, O, PDL and PAL) were plotted as scattered diagrams and the different linear regression equations were calculated as follow:

while TW against SL were described by:

$$
\text { Morphometric parameter }=a+b \times T L
$$

$$
T W=a \times S L^{b}
$$

The coefficient of correlation $\mathrm{R}^{2}$, and the standard error SE were estimated (Statgraphics, 2005). The meristic characteristics were counted as: Dorsal fin (D) rays + spines, Anal fin (A) rays + spines, ventral fin $(\mathrm{V})$ rays + spines and Pectoral fin $(\mathrm{P})$ ray and spines.

\section{- Length-weight relationship}

The length weight relationships were estimated from the allometric equation;

$$
T W=a \times T L^{b} \text { (Ricker, 1973) }
$$

where (TW) total body weight (g), (TL) the total length $(\mathrm{cm})$, a and b are the coefficients of the functional regression between (W) and (L). 


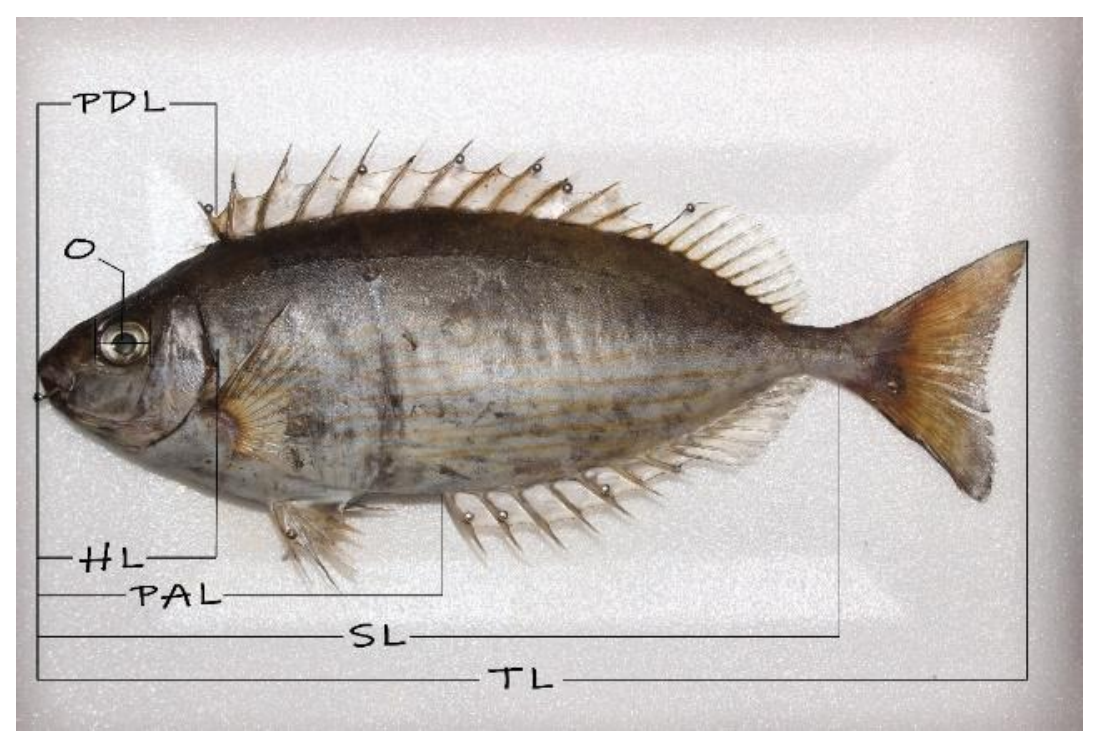

Fig (2): Raw measurements of Siganus rivulatus; total length (TL), standard length (SL), head length (HL), pre dorsal length (PDL), pre anal length (PAL), orbit length (O) -the length between the anterior and posterior margins of the eye.

\section{- Condition factor}

Absolute or Fulton's coefficient $(\mathrm{Kf})$ and relative or Clark's coefficient $(\mathrm{Kc})$ were calculated using the equations:

$$
\begin{aligned}
-\quad K f & =\left(\frac{T W}{T L^{3}}\right) \times 100 \quad(\text { Fulton, 1902) } \\
-\quad K C & =\left(\frac{G W}{T L^{3}}\right) \times 100 \text { (Clark, 1928), }
\end{aligned}
$$

where, $(\mathrm{Kf})$ is Fulton's condition factor, $(\mathrm{Kc})$ is Clark's condition factor, $(\mathrm{TW})$ is the total weight of fish, $(\mathrm{GW})$ is the gutted weight, and (TL) is the observed Total Length $(\mathrm{cm})$.

The specimens of each site were grouped into a $1 \mathrm{~cm}$ length classes, then $\mathrm{Kf}$ and $\mathrm{Kc}$ were estimated as seasonal average for each investigated area, and for different length-classes

\section{- Statistical analysis}

All statistical tests, mean, range values, standard deviation and simple linear regression were estimated using the program Microsoft® Excel 2002. One-way ANOVA analysis was used for $\mathrm{TL}, \mathrm{SL}, \mathrm{TW}, \mathrm{Kf}$ and $\mathrm{Kf}$, with statistically significant at $(P \leq 0.05)$, to compare between different studied area using SPSS for windows (11.0.0), (copyright@ SPSS Inc.).

\section{RESULTS}

\section{- Length-frequency distribution}

Length frequency distribution of $S$. rivulatus were estimated for all collected individuals (1741) in the present study. The TL of fish from the Red Sea $(n=334)$ was fluctuated between $14-28 \mathrm{~cm}$, with the most frequent length class of 16-16.9 cm (14.37\%), while TL of specimens from the Suez Canal $(n=581)$ and the Mediterranean $(n=826)$ ranged between 8 and 22cm, with the mode of 10-10. (25.3\%) and 12-12.9 cm (15.25\%), respectively (Fig. 3). 


\section{(a) Red Sea}

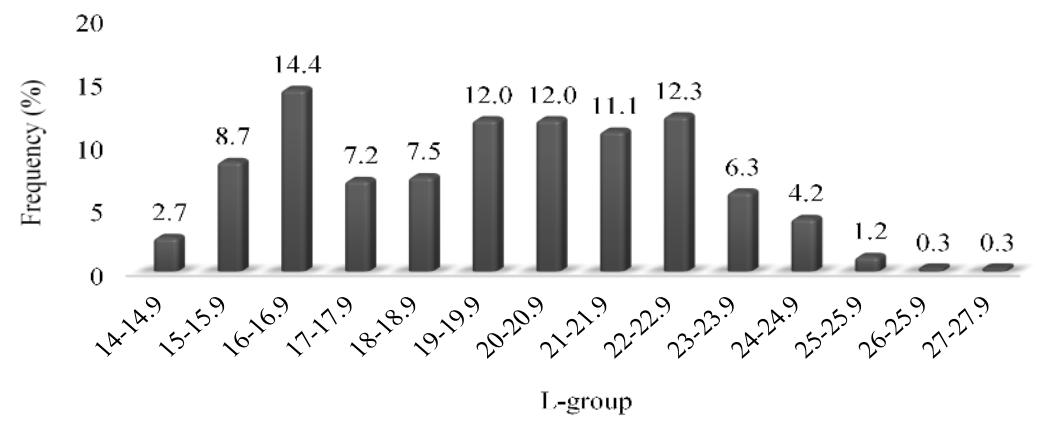

(b) Suez Canal

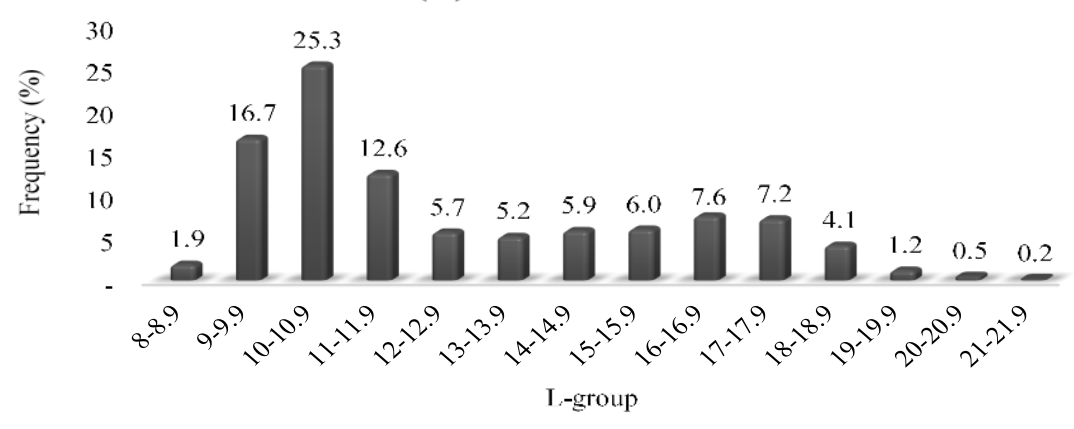

(c) Mediterranean Sea

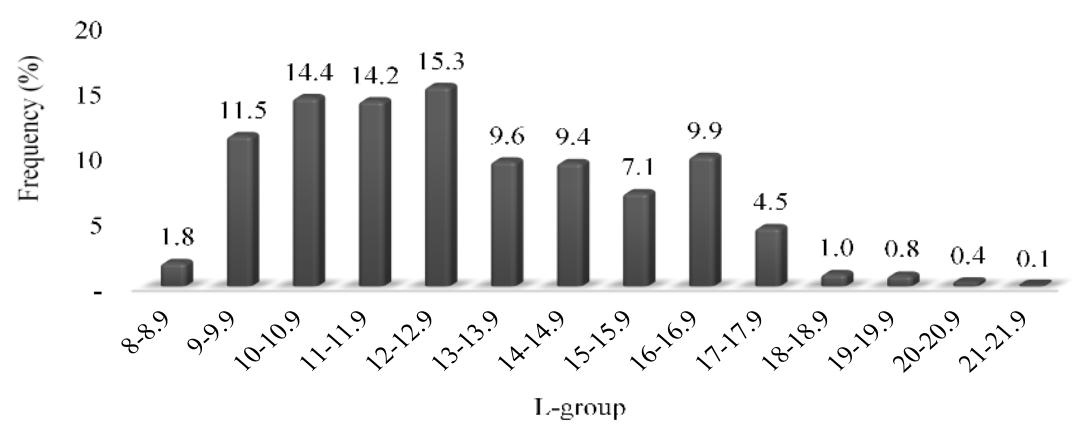

Fig (3): Length frequency distribution of S. rivulatus collected from Red Sea (a), Suez Canal (b) and Mediterranean Sea (c).

\section{- Relations of morphometric and meristic parameters}

As shown in Table (1); the Red Sea population had the highest values for all investigated morphometric measurements; TL, SL, HL, width, PDL, PAL, O, IO, TW, and GW, while the measurements of Suez Canal and Mediterranean populations were close to each other. The morphometric parameters TL, SL and TW showed significant differences between sites (ANOVA, $P \unlhd 0.05$ ). The morphometric regressions of TW against SL and TL against each of SL, width, HD, O, PDL and PAL for the Red Sea, Suez Canal and Mediterranean demonstrated positive allometric growth (Table 2). The meristic equations of all studied sites were approximately similar; D, XIV+10; A, VII+9; V, I+3+I; P, 15-16 (Table 2). 
Table (1): Morphological measurements for S. rivulatus (Mean \pm standard deviation (SD), minimum (Min.)-maximum (Max.) and proportion of total length (\% of TL) collected from (a) Red Sea, (b) Suez Canal and Mediterranean Sea.

\begin{tabular}{|c|c|c|c|c|c|c|c|c|c|}
\hline \multirow[t]{2}{*}{ Area } & \multicolumn{3}{|c|}{ Red Sea } & \multicolumn{3}{|c|}{ Suez Canal } & \multicolumn{3}{|c|}{ Mediterranean Sea } \\
\hline & mean $\pm \mathrm{SD}$ & Min.-Max. & $(\%)$ of $\mathrm{TL}$ & mean $\pm S D$ & Min.-Max. & $(\%)$ of $\mathrm{TL}$ & mean $\pm \mathrm{SD}$ & Min.-Max. & $(\%)$ of $\mathrm{TL}$ \\
\hline $\mathrm{TL}(\mathrm{cm})$ & $20.09 \pm 2.75$ & $14.1-27.9$ & 100 & $13.64 \pm 3.13$ & $8.2-21.1$ & 100 & $13.31 \pm 2.72$ & $8.1-21.1$ & 100 \\
\hline $\mathrm{SL}(\mathrm{cm})$ & $15.83 \pm 2.15$ & $11.3-22.3$ & 78.79 & $10.77 \pm 2.46$ & $6.3-17$ & 78.94 & $10.47 \pm 2.09$ & $6.1-16.6$ & 78.68 \\
\hline $\mathrm{HL}(\mathrm{cm})$ & $3.80 \pm 0.49$ & $2.7-5.3$ & 18.92 & $2.68 \pm 0.51$ & $1.7-3.9$ & 19.68 & $2.65 \pm 0.49$ & $1.8-4$ & 19.87 \\
\hline Width $(\mathrm{cm})$ & $6.03 \pm 0.89$ & $3.8-8.6$ & & $4.12 \pm 0.97$ & $2-7$ & & $3.80 \pm 0.77$ & $2.2-7.2$ & \\
\hline PDL (cm) & $4.11 \pm 0.70$ & $2.5-6$ & 20.46 & $3.16 \pm 0.66$ & $1.9-4.7$ & 23.14 & $2.94 \pm 0.69$ & $1.8-5.3$ & 22.06 \\
\hline PAL $(\mathrm{cm})$ & $8.57 \pm 1.27$ & $6-12$ & 42.66 & $6.05 \pm 1.39$ & $3.5-9.2$ & 44.38 & $5.70 \pm 1.21$ & $3.5-9.1$ & 42.82 \\
\hline $\mathrm{O}(\mathrm{cm})$ & $0.97 \pm 0.11$ & $0.7-1.4$ & 25.53 of $\mathrm{HL}$ & $0.76 \pm 0.12$ & $0.5-1.1$ & 28.17 of $\mathrm{HL}$ & $0.73 \pm 0.14$ & $0.4-1.1$ & 27.49 of $\mathrm{HL}$ \\
\hline $\mathrm{IO}(\mathrm{cm})$ & $1.41 \pm 0.23$ & $0.9-2$ & & $0.96 \pm 0.22$ & $0.6-1.6$ & & $0.86 \pm 0.18$ & $0.5-1.4$ & \\
\hline $\mathrm{TW}(\mathrm{g})$ & $106.7 \pm 42.78$ & $31.4-277.4$ & & $41.44 \pm 28.4$ & $6.6-132.3$ & & $32.51 \pm 20.23$ & $6-115.34$ & \\
\hline GUT. W (g) & $81.81 \pm 33.29$ & 20.8-189 & 76.67 of TW & $31.45 \pm 21.93$ & $3.4-105.4$ & 75.88 of $\mathrm{TW}$ & $25.25 \pm 15.79$ & $4.5-96$ & 77.65 of $\mathrm{TW}$ \\
\hline
\end{tabular}

Table (2): The linear regression analysis of morphometric parameters of S. rivulatus in the Red Sea, Suez Canal and Mediterranean

\begin{tabular}{|l|l||c|c|c|c|c|c|c|c|} 
Sea. \\
Sites
\end{tabular}




\section{- Length-weight relationship of $S$. rivulatus}

Total length (TL) of all individuals collected from Red Sea ranged between 14.1 and $27.9 \mathrm{~cm}$ (average: $20.09 \pm 2.75 \mathrm{~cm}$ ) and total weight (TW) fluctuated between 31.4 and $277.4 \mathrm{~g}$ (average: $106.71 \pm 42.78 \mathrm{~g}$ ). The TL range was $(8.2-21.1 \mathrm{~cm})$ in both Suez Canal and Mediterranean specimens; with an average of $13.46 \pm 3.13 \mathrm{~cm}$ and $13.31 \pm$ $2.72 \mathrm{~cm}$, respectively. The TW ranged from 6.6 to $132.3 \mathrm{~g}(41.11 \pm 28.4 \mathrm{~g})$ in Suez Canal and from 6 to $115.34(32.51 \pm 20.23 \mathrm{~g})$ in Mediterranean (Table 1).

The length-weight relationship equations of $S$. rivulatus were $\mathrm{W}=0.0112 \mathrm{~L}^{3.0349}$, $\mathrm{W}=0.0085 \mathrm{~L}^{3.1825}$, and $\mathrm{W}=0.0154 \mathrm{~L}^{2.9091}$ with correlation coefficients $\left(\mathrm{R}^{2}\right)$ of 0.9492 , 0.9834 and 0.9324 for Red Sea, Suez Canal and Mediterranean, respectively (Fig. 4). The exponent $b$ values indicated positive allometric growth in the Suez Canal population while it was isometric in the Red and Mediterranean Seas populations.

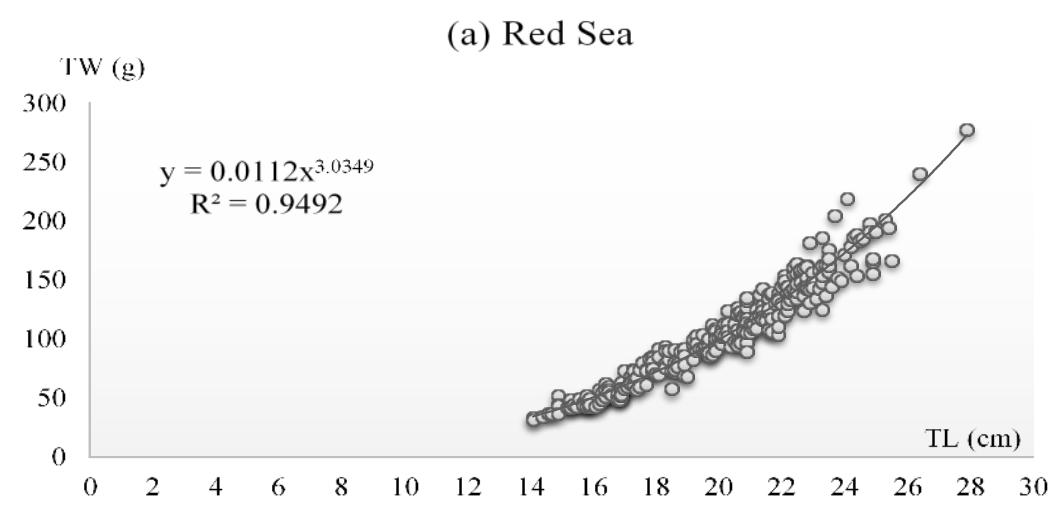

(b) Suez Canal

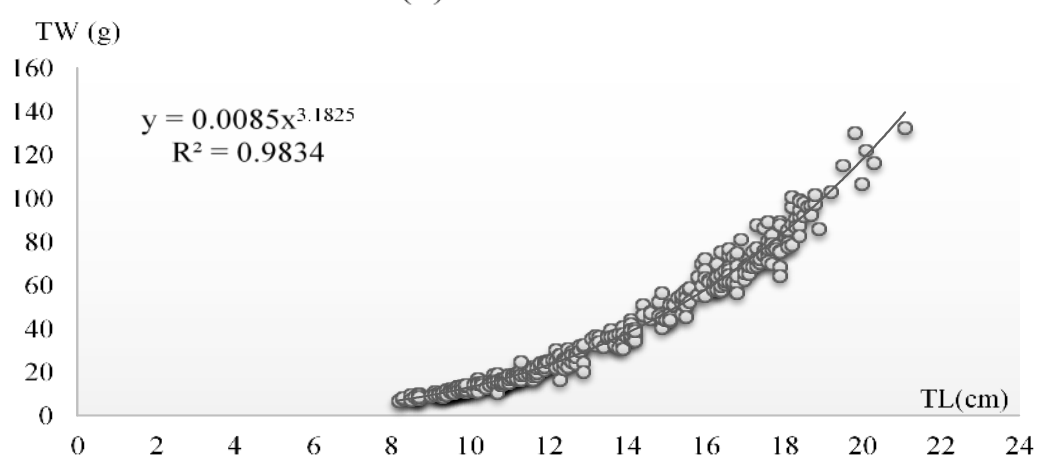

(c) Mediterranean Sea

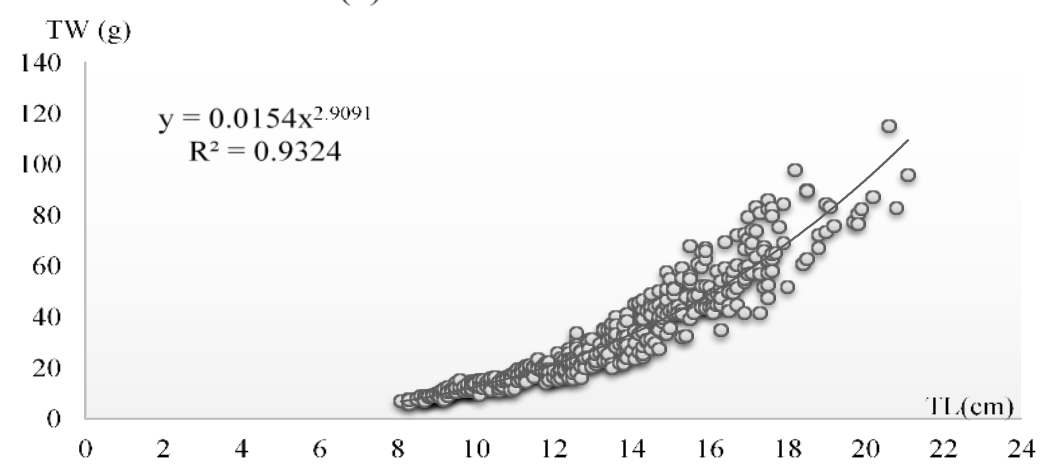

Fig (4): Length weight relationship of S. rivulatus in the Red Sea (a), Suez Canal (b) and Mediterranean Sea (c). 


\section{- Condition factor (K)}

Fulton condition factor (Kf) of $S$. rivulatus displayed the same seasonal variation pattern in all studied areas; giving the highest values in summer (1.341, 1.4628 and 1.2833) and the lowest values in winter $(1.217,1.3199$ and 1.1498) in Red Sea, Suez Canal and Mediterranean, respectively (Fig. 5a, b \&c). On the other hand, Clark condition factor $(\mathrm{Kc})$ demonstrated similar pattern in both Suez Canal and the Mediterranean (Fig. 5b\&c), with the highest values in summer (1.1198 and 1.0308, respectively) and the lowest values in winter (0.9819 and 0.9005, respectively). Conversely, Kc in the Red Sea showed different pattern (Fig. 5a) when the highest value was recorded in autumn (1.022) and unusual decrease was observed during spring (0.913). Both $\mathrm{Kf}$ and $\mathrm{Kc}$ showed significant differences between the studied areas (ANOVA, $P \leq 0.05$ ).

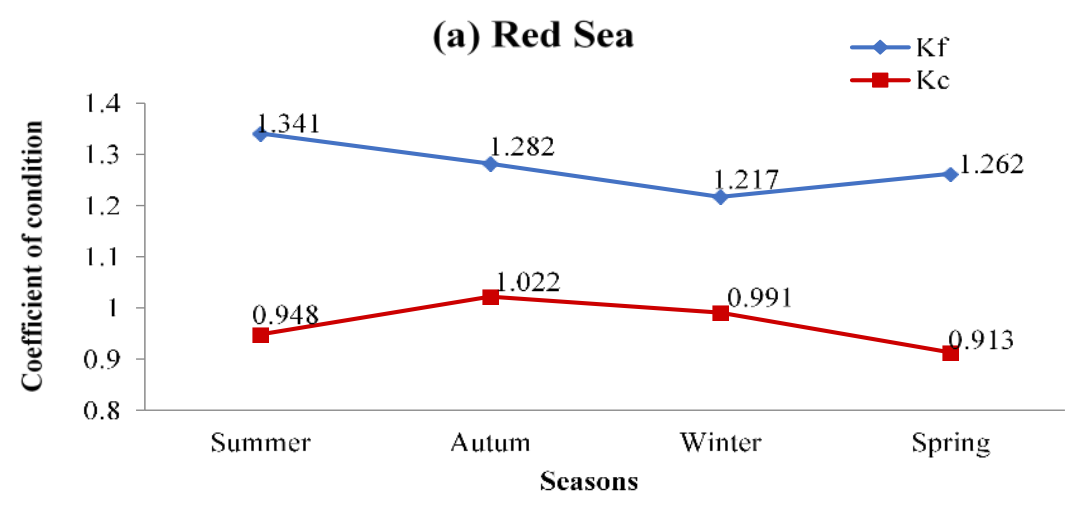

(b) Suez Canal

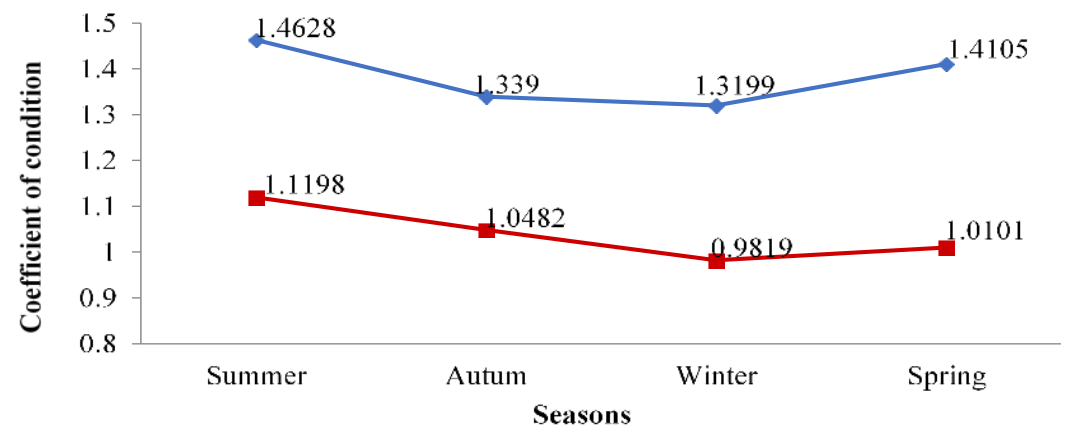

(c) Mediterranean Sea

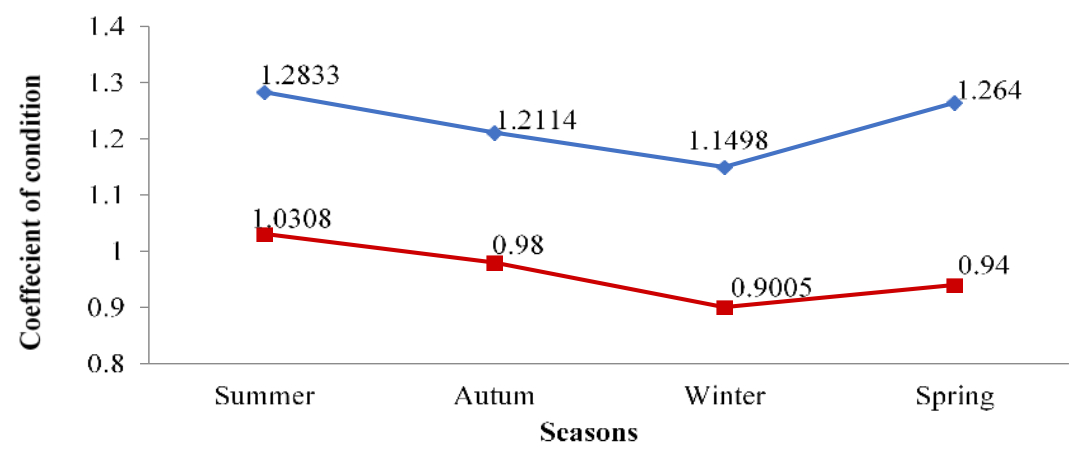

Fig (5): Seasonal variation in Fulton's and Clark's coefficient (Kf and Kc) of $S$. rivulatus at Red Sea (a), Suez Canal (b) and Mediterranean Sea (c). 
Variation in $\mathrm{Kf}$ and $\mathrm{Kc}$ values of $S$. rivulatus with length groups were estimated at each studied area (Fig. 6). Kf values showed fluctuation between different length groups, with irregular trend. The values ranged from 1.312 to 1.163 in Red Sea (Fig. 6a), 1.503 to 1.329 in Suez Canal (Fig. 6b) and 1.34 to 1.104 in the Mediterranean Sea (Fig. 6c). On the other hand, Kc showed similar trend in all location in which the values decreased with increasing length. It decreased from 1.01 in length group $16 \mathrm{~cm}$ to 0.796 in $25 \mathrm{~cm}$ in Red Sea (Fig. 6a), from 1.11 in length group $11 \mathrm{~cm}$ to 0.854 in $20 \mathrm{~cm}$ in Suez Canal (Fig. 6b), and from 1.015 in length group $9 \mathrm{~cm}$ to 0.754 in $21 \mathrm{~cm}$ in Mediterranean Sea (Fig. 6c).
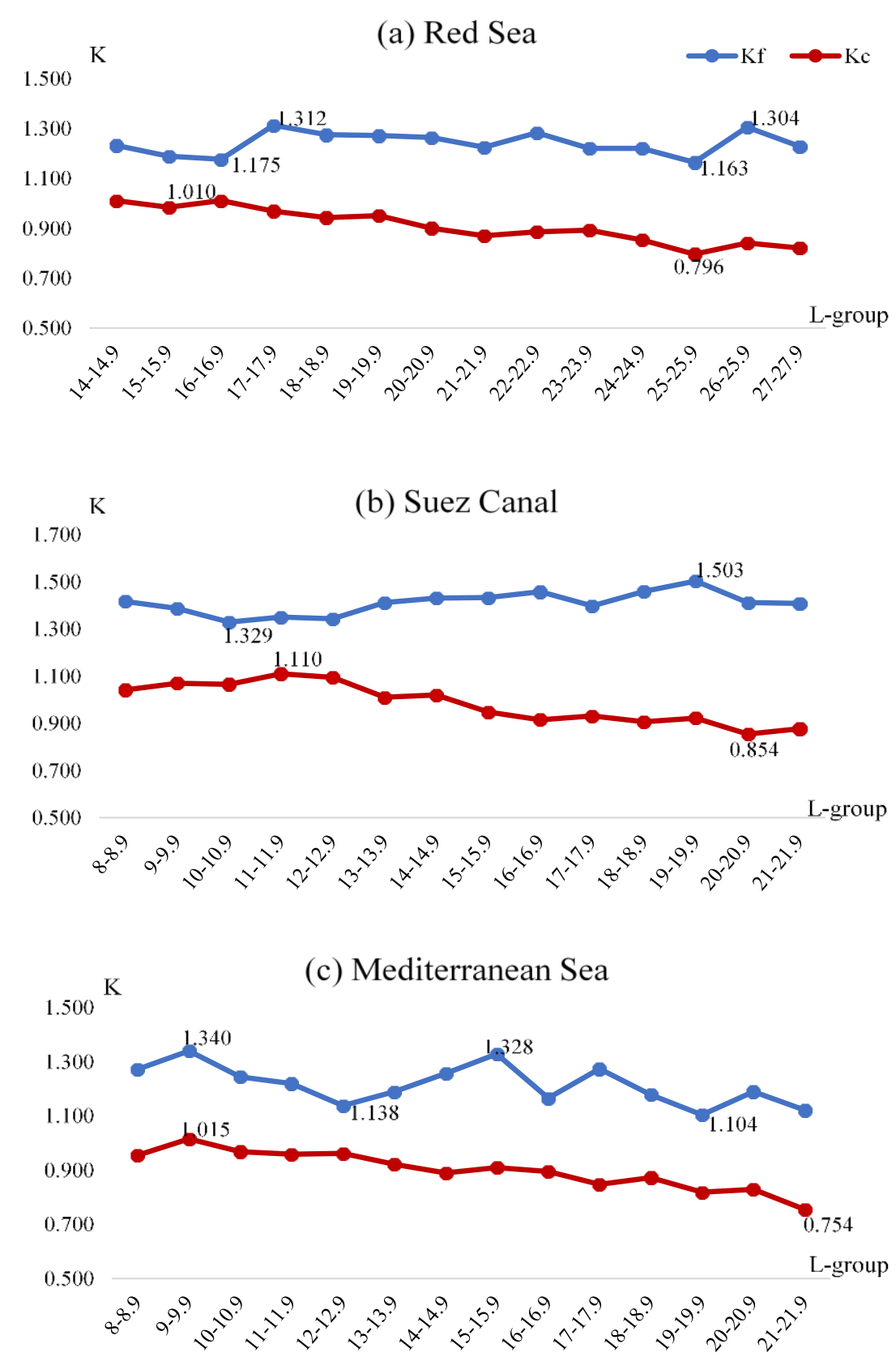

Fig (6): Fulton's and Clark's coefficients for length groups of S. rivulatus collected from Red Sea (a), Suez Canal (b) and Mediterranean Sea (c). 


\section{DISCUSSION}

Siganus rivulatus is a commercially important fish species in the Egyptian marine waters (Red Sea, Suez Canal and Mediterranean Sea). It is one of the most abundant fishes caught by different artisanal gears, particularly trammel and gill nets in the marine small-scale fisheries of Egypt (Saber \& Gewida, 2020). Its catch was about 500 tons from Red Sea and 828 tons from Mediterranean during 2018 (GAFRD, 2019).

Biometric characters (morphometric indices, morphometric regression and merestic characters) of $S$. rivulatus were investigated to identify local stocks of this species. Morphometric indices have been of common use by ichthyologists to differentiate between different races of the same fish species, or fishes of the same species living in different localities (Skelton, 1976).

In the present study, the modal size $S$. rivulatus was $16.5 \mathrm{~cm}$ in the Red Sea, $10.5 \mathrm{~cm}$ in Suez Canal and $12.5 \mathrm{~cm}$ in the Mediterranean Sea. These lengths were smaller than those recorded in previous studies in each location such as; $12 \mathrm{~cm}$ on Lebanese coast (Bariche, 2005), $16.2 \mathrm{~cm}$ at Alexandria coast (EI-Far, 2008), $18 \mathrm{~cm}$ at Bitter lake (El-Drawany, 2015) and Libyan coast (Shakman et al., 2008). The variability in the most frequented length could be due to various fishing gears used in sampling, as reported by El-Far (2008) when he recorded difference in the most frequented length of $S$. rivulatus at the same site and time $(13,16$ and $17 \mathrm{~cm})$ caught by nylon trammels with different mesh sizes $(2.08,2.27,2.5 \mathrm{~cm}$, respectively).

The relationships between total length and different studied morphometric measurements were positively correlated at all studied areas. The same was observed for S. rivulatus on Libyan coast (Shakman et al., 2008). There was no significant difference in the meristic counts (D, XIV+10; A, VII+9; V, I+3+I; P, 15-16) between different locations. In agree, the meristic formula of family Siganidae was described by Woodland (1990) as (D, XIV + 10; A, VII + 8-10; V, I + 3 +I; P, 15-17) and that of $S$. rivulatus was stated by Shakman $\boldsymbol{e t}$ al. (2008) as D, XIV+10; A, VII+8-10; V, I+3+I. Any change in meristic counts of Lessepsian migrant species is a combination of shifting or shortening of the spawning seasons and the different temperature regimes between the two seas (Golani, 1990).

Studying of length-weight relationship is very important in fisheries science as it used for forecasting the potential yield and determining the most favorable size of capture to obtain optimum yield; these management parameters are directly related to the weight of the fish (Suresh $\boldsymbol{e t}$ al., 2006). The value of 'b' is the key parameter in estimating population growth through length-weight relationship (Simon \& Mazlan, 2008), it is usually close to 3 in all fish, despite many variations of fish forms and may fall in the range of 2.5-3.5 (King, 1996). The length-weight relationship is considered isometric when the value of $\mathrm{b}$ equal to 3 , while it is allometric when the value is higher or lower than 3 (Ricker, 1975). The $b$ value usually used to show the robustness of the fish and compare the condition of the fish (Le Cren, 1951). In the present study, b values of $S$. rivulatus were found to be 3.0349, 3.1825 and 2.9091 in Red Sea, Suez Canal and Mediterranean Sea, respectively. These results agree with the findings of Gayanilo \& Pauly (1997).

Table (3) summarizes the findings of previous studies on the length weight relationship of $S$. rivulatus and our results. The differences in b values could be due to 
differences in growth and morphometry between regions (Barnabe, 1976). Froese (2006) interpret the differences in b values within the same species by a number of abiotic factors such as temperature which vary with geographical distribution, habitats, food availability in the environment, season and fishing vessels or biotic factors such as recorded lengths of the caught specimens, age, stomach fullness, sex and gonad maturity.

Table 3. Length-weight relationship of $S$. rivulatus from the present study and the previous studies in different locations.

\begin{tabular}{|c|c|c|c|c|c|c|c|}
\hline Author & Location & Sex & $\mathbf{a}$ & $\mathbf{b}$ & $\mathbf{R}^{2}$ & $\mathbf{n}$ & $\begin{array}{c}\text { size rang } \\
(\mathbf{c m})\end{array}$ \\
\hline \multirow[t]{3}{*}{ Preen Study } & Red Sea (Hurghada) & $\overline{\mathrm{C}}$ & 0.0112 & 3.0349 & 0.9492 & 334 & $14.1-27.9$ \\
\hline & Suez Canal (Ismailia) & $\mathrm{C}$ & 0.0085 & 3.182 & 0.9834 & 581 & $8.2-21.1$ \\
\hline & $\begin{array}{l}\text { Mediterranean (Port- } \\
\text { Said) }\end{array}$ & $\mathrm{C}$ & 0.0154 & 2.9091 & 0.9324 & 826 & $8.1-22.1$ \\
\hline \multicolumn{8}{|c|}{ Red Sea } \\
\hline Hashem, 1983 & Saudi Arabia & $\mathrm{C}$ & 0.021 & 3.071 & & 898 & $11-30$ \\
\hline El-Gammal, 1988 & Egypt (Hurghada) & $\begin{array}{l}\mathrm{M} \\
\mathrm{F}\end{array}$ & $\begin{array}{l}0.012 \\
0.011\end{array}$ & $\begin{array}{l}2.838 \\
2.841\end{array}$ & $\begin{array}{l}0.99 \\
0.99\end{array}$ & $\begin{array}{l}114 \\
137\end{array}$ & - \\
\hline $\begin{array}{l}\text { Tharwat \& Al- } \\
\text { Owafeir, 2003 }\end{array}$ & Saudi Arabia & $\mathrm{C}$ & 0.013 & 2.990 & 0.99 & 200 & $150-270$ \\
\hline Gabr et al., 2018 & Saudi Arabia (Jeddah) & $\mathrm{C}$ & 0.011 & 3.06 & 0.96 & $\begin{array}{c}217 \\
7\end{array}$ & $11.3-28.3$ \\
\hline \multicolumn{8}{|c|}{ Suez Canal } \\
\hline El-Drawany, 2015 & Bitter Lakes, Egypt & $\begin{array}{l}\mathrm{M} \\
\mathrm{F}\end{array}$ & $\begin{array}{l}0.01042 \\
0.00952\end{array}$ & $\begin{array}{l}3.010 \\
3.042 \\
\end{array}$ & $\begin{array}{l}0.98 \\
0.98\end{array}$ & & $\begin{array}{l}9-28.5 \\
9-28.9\end{array}$ \\
\hline \multicolumn{8}{|c|}{ Mediterranean Sea } \\
\hline Mouneimne, 1978 & Lebanon (Junieh) & $\mathrm{C}$ & 0.071 & 3.142 & - & 458 & $5-25.2$ \\
\hline Mohammed, 1991 & Egypt & $\begin{array}{l}\mathrm{M} \\
\mathrm{F} \\
\mathrm{C}\end{array}$ & $\begin{array}{l}0.018 \\
0.017 \\
0.012\end{array}$ & $\begin{array}{l}2.830 \\
2.866 \\
2.934\end{array}$ & $\begin{array}{l}0.99 \\
0.99 \\
0.99\end{array}$ & - & - \\
\hline EL-Okda, 1998 & Egypt & $\mathrm{C}$ & 0.016 & 2.872 & - & 1126 & $110-280$ \\
\hline $\begin{array}{l}\text { Taskavak \& } \\
\text { Bilecenoglu, 2001 }\end{array}$ & Turkey & $\mathrm{C}$ & 0.047 & 3.203 & 0.98 & 355 & $107-241$ \\
\hline Abdallah, 2002 & Egypt (Alexandria) & $\mathrm{C}$ & 0.022 & 2.820 & 0.93 & 112 & $55-27.6$ \\
\hline $\begin{array}{l}\text { Bilecenoglu \& } \\
\text { Kaya, } 2002\end{array}$ & Turkey (Antalya) & $\begin{array}{l}\mathrm{M} \\
\mathrm{F} \\
\mathrm{C}\end{array}$ & $\begin{array}{l}0.075 \\
0.064 \\
0.071\end{array}$ & $\begin{array}{l}3.135 \\
3.221 \\
3.179\end{array}$ & $\begin{array}{l}0.95 \\
0.95 \\
0.95\end{array}$ & $\begin{array}{l}229 \\
292 \\
521\end{array}$ & $\begin{array}{c}7.1-20.6 \\
7-21.5 \\
7-21.5\end{array}$ \\
\hline Bariche, 2005 & Lebanon (Batrun) & $\begin{array}{l}\mathrm{M} \\
\mathrm{F} \\
\mathrm{C}\end{array}$ & $\begin{array}{l}0.020 \\
0.010 \\
0.010 \\
\end{array}$ & $\begin{array}{c}3.323 \\
3.011 \\
3.04 \\
\end{array}$ & $\begin{array}{l}0.95 \\
0.96 \\
0.99 \\
\end{array}$ & $\begin{array}{c}98 \\
93 \\
781 \\
\end{array}$ & $\begin{array}{l}12.7-23.2 \\
12.6-26.7 \\
24.8-26.7\end{array}$ \\
\hline El-Far, 2008 & Egypt (Alexandria) & $\begin{array}{l}\mathrm{M} \\
\mathrm{F} \\
\mathrm{C} \\
\end{array}$ & $\begin{array}{l}0.039 \\
0.017 \\
0.023 \\
\end{array}$ & $\begin{array}{l}2.594 \\
2.906 \\
2.783 \\
\end{array}$ & $\begin{array}{l}0.97 \\
0.98 \\
0.93 \\
\end{array}$ & $\begin{array}{c}586 \\
617 \\
1217 \\
\end{array}$ & $\begin{array}{c}10.9-25.9 \\
9.7-22.9 \\
8.6-25.9\end{array}$ \\
\hline $\begin{array}{l}\text { Shakman et al., } \\
2008\end{array}$ & Libyan coast & $\mathrm{C}$ & 0.0233 & 2.82 & 0.93 & 1672 & $6.2-27.4$ \\
\hline Hagras, 2015 & Bardawil lagoon & $\begin{array}{l}\mathrm{M} \\
\mathrm{F} \\
\mathrm{C} \\
\end{array}$ & $\begin{array}{l}0.0141 \\
0.0161 \\
0.0163\end{array}$ & $\begin{array}{c}2.9584 \\
2.905 \\
2.8971\end{array}$ & & $\begin{array}{c}606 \\
617 \\
4066 \\
\end{array}$ & $\begin{array}{l}7-20.9 \\
8-21.9 \\
7-21.9 \\
\end{array}$ \\
\hline
\end{tabular}


Condition factor is widely used to express the stability of an environment to a certain fish species (El-Far, 2008), it indicates its fatness, general wellbeing and gonad development (Hile, 1936). Fulton (1902) was the first to calculate the condition factor "Kf" using a total body weight (absolute condition factor), based on the hypothesis that the heavier fish of a given length is in better condition. Gutted weight $(\mathrm{GW})$ could be used instead of total weight (TW) in calculation of condition factor "Kc" in order to exclude the effect of stomach content and the weight of gonad which may mask the true of fish condition (Lagler, 1956; Ricker, 1975).

The absolute condition factor values (Kf) in the present study showed that the temperature was one of the most effective parameters in condition of the fish, as it had the highest values in summer and the lowest in winter at all studied locations, the values in autumn and spring were close (Fig. 5). It is indicating to the suitability of the environment with regards to feeding condition or reproductive strategy. Yeldan \& Avsar (2000) stated that Fulton's Condition Factor is opposite to gonadosomatic index (GSI) due to the inverse relationship between the gonadal development and the food elements deposited in the muscle tissue, such that when the GSI increases the Kf is expected to decrease.

When we used the GW instead of the TW in calculation of condition factor, the Kc values showed the same pattern in Suez Canal and Mediterranean except during spring season when it decreased more than other, which mean the gonads and stomach were very heavy. This confirm the observation of spring being the reproductive season, when fish consume most of the food in gonads development instead of the food elements deposited in the muscle tissues of fish. In Red Sea, the Kc values showed much more decreasing in spring, in addition to decreasing in summer also even became lower than the values in autumn and winter, this may due to extension of the reproductive season in Red Sea during summer, and to the fully stomach observed in stomach analysis (unpublished data). Welcome (1979) mentioned that, the condition factor influences the reproductive cycle in fish. In agreement with the present Kf results of $S$. rivulatus; Hagras (2015) recorded the highest value in Bardawil lagoon in September (summer) and the lowest in December and January (winter) followed by that recorded during spawning time. Barchie et al. (2009) stated that Kf of the same species at Lebanese coasts (eastern Mediterranean) decreased during the spawning season, and increased again after spawning, and reached a minimum in February (winter). Shakman (2008) estimated little differences between seasons on Libyan coasts; but the lowest values still observed in December and January (winter) and during spawning months. Yeldan \& Avsar (2000) recorded the biggest decrease of $\mathrm{Kf}$ value in December and the maximum in July. This situation was similar in Jeddah, Red Sea populations (Hashem, 1983) where $\mathrm{K}$ values decreased during maturation and spawning activities. The data from the Red Sea and Suez Canal population is scarce and incomplete. El-Far, (2008) used gutted weight to estimate the condition factor $(\mathrm{Kc})$ of $S$. rivulatus on Alexandria coast, the results agreed with the present study in winter (January and February when the lowest values of Kc were observed in the Mediterranean, while the highest value was recorded in May. D'Ancone (1963) pointed out that the coefficient of condition varies with the state of gonad maturity, months, seasons, climate and possibly with age. The condition factor is directly related to environmental conditions (Clesceri $\boldsymbol{e t}$ al., 1999) and changes in $\mathrm{K}$, for several fishes have been ascribed to a depletion of body reserves during gonad maturation (Htun-Han, 1978). There were significant 
differences recorded in values of $\mathrm{Kf}$ and $\mathrm{Kc}$ between the studied areas (ANOVA, $P \unlhd 0.05)$.

The fluctuation of $\mathrm{Kf}$ values with different length group in Red Sea (1.1631.312), Suez Canal (1.329-1.503) and Mediterranean (1.104-1.34) may be due to the fact of; while the smaller fish needs more energy to grow, the larger fish usually contain mature gonads and full stomach which had heavy weight. Tharwat \& AlOwafier (2003) recorded similar range for S. rivulatus inhabit the Red Sea (1.1-1.3).

On the other hand, the observed decline in Kc values with increasing fish length could be returned to; having bigger and more full stomach as observed in stomach analysis work (unpublished data), and to consume almost of the food for the development of reproductive cells (gonads maturation) instead of the growing muscles of the body (Yeldan \& Avsar, 2000), while higher Kc in fish with smaller length reflecting the accordance with high growth pattern of small fish when fish deposited almost of the food elements in the tissues of its muscle to grow well. This result is in agreement with the study of El-Far (2008) who recorded decreasing of $\mathrm{K}$ values (using GW) in males, females and combined sexes of $S$. rivulatus on Alexandria coast with increasing length of the fish. Inversely, Tharwat \& AlOwafier (2003) discussed the condition factor for S. rivulatus in the Red Sea and showed a gradual increase in values of absolute and relative condition factor with increasing fish length

\section{REFERENCES}

Abdallah, M. (2002). Length-weight relationship of fishes caught by trawl off Alexandria, Egypt. Naga ICLARM Q., 25: 19-20.

Abdelhak, E M.; Madkour, F.F; El Ganainy, A.A; Abu El-Regal, M.A. and Ahmed, M.I. (2020). Reproductive biology of Siganus rivulatus (Forsskal, 1775) in the Red Sea, Suez Canal and the Mediterranean Sea, Egypt. Egyptian Journal of Aquatic Biology \& Fisheries, 24(6): 117 - 134. DOI: 10.21608/ EJABF. 2020.110701

Alam, M.M.; Rahman, M.T. and Parween, S. (2014). Morphometric characters and condition factors of five freshwater fishes from Pagla River of Bangladesh. International Journal of Aquatic Biology, 2(1):14-19.https://doi.org/ 10.22034/ ijab.v2i1.18

Aleem, A. (1969). Marine resources of the United Arab Republic. Studies and reviews. Gen. Fish. Counc. Med. (FAO), 43: 1-22.

Bariche M. (2005). Age and growth of Lessepsian rabbitfish from the eastern Mediterranean. J. App. Ichthyol., 21: 141-145. DOI: 10.1111/j.1439-0426. 2004.00619.x

Bariche M.; Letourneur, Y. and Harmelin, M. (2004). Temporal fluctuations and settlement patterns of native and Lessepsian herbivorous fishes on the Lebanese coast (eastern Mediterranean). Environ. Biol. Fishes, 70: 81-90.

Bariche, M.; Sadek, R. and Azzurro, E. (2009). Fecundity and condition of successful invaders: Siganus rivulatus and S. luridus (Actinopterygii: Perciformes: 
Siganidae) in the eastern Mediterranean Sea. Acta Ichthyologica et Piscatoria, 39(1), 11-18. http://doi:10.3750/AIP2009.39.1.03

Barnabe, G. (1976). Contrbution à la connaissance de la biologie du loup, Dicentrarchus labrax L. (Serranidae) de la région de Sète. Thèse Doct. D’État, Université du Languedoc. Montpellier, 426pp.

Ben-Tuvia, A. (1978). Immigration of fishes through the Suez Canal. Fish. Bull. 76: 249.

Ben-Tuvia, A. (1985). The impact of the Lessepsian (Suez Canal) fish migration on the eastern Mediterranean ecosystem, Pp. 367-375. In: MoraitouApostolopoulou M., Kiortsis V. (eds.) Mediterranean Marine Ecosystems. Plenum Press, NewYork.

Bilecenoglu, M. and Kaya, M. (2002). Growth of marbled spinefoot, Siganus rivulatus, Forsskål, 1775 (Teleostei: Siganidae) introduced to Antalya Bay, eastern Mediterranean Sea (Turkey). J. Fish. Res., 54 (2): 279-285. DOI: 10.1016/S0165-7836(00)00296-4

Clark, F.N. (1928). The weight-length relationship of the California sardine (Sardinella caerulea) at San Pedro, Division of Fish and Game. Fish Bull, No. 12, 59pp.

Clesceri L.S.; Greenberg A.E. and Eaton A.D. (1999). Standard methods for the examination of water and wastewater. American Public Health Association, Washington.

D'Ancone, M.V. (1963). La crossance chez les animaux de la Miditerranees. Rpp. Comm. Int. Mer. Med., 10.

Dan-Kishiya, A.S. (2013). Length-weight relationship and condition factor of five fish species from a tropical water supply reservoir in Abuja, Nigeria. American Journal of Research Communication, 1(9): 175-187.

Diamant, A. (1989). Lessepsian migrants as hosts: a parasitological assessment of rabbitfish, Siganus luridus and S. rivulatus (Siganidae), in their original and new zoogeographical regions, In: Environmental Quality and Ecosystem Stability-Environmental Quality. ISEEQS Pub., Jerusalem, pp. 187-194.

El-Drawany, M. (2015). On the biology of Siganus rivulatus inhabits Bitter Lakes in Egypt. J Aquac. Res. Dev., 6(6), 342. DOI: 10.4172/2155-9546.1000342

El-Gammal, F.I. (1988). Age, growth and mortality of the rabbit fish Siganus rivulatus (Forsskål, 1775), from the Red Sea. Bull. Inst. Oceanogr. Fish. ARE., 14: 13-21.

El-Ganainy A.A. and Ahmed, A.I. (2002). Growth, mortality and yield -per- recruit of the rabbitfish, Siganus rivulatus, from the eastern side of the Gulf of Suez, Sinai Coast, Red Sea, Egypt. Egypt. J. Aquat. Biol. Fish, 6(1): 67-81.

El-Far, A.M.M. (2008). Artisanal fisheries along Alexandria coast area with special reference to the fishery biology of Siganus spp. (M.Sc. Thesis), Department of Zoology, Faculty of Science, Zagazig University, Egypt. 
El-Okda, N.I. (1998). Comparative studies on certain biological aspects of Siganus in marine waters of Egypt (Ph.D. Thesis). Fac. Sci. Zagazig, Univ.

Fischer, W and Bianchi, G. (1984). FAO species identification sheets for fishery purposes. Western Indian Ocean (Fishing Area 51), FAO, Rome, (2): 1-6.

Froese, R. and Pauly, D. (2004). A global information system on fishes. [Online]. Available from: http://www.fishbase.org

Froese, R. (2006). Cube law, condition factor and weight-length relationships: history, meta-analysis and recommendations, Journal of Applied Ichthyology, 22: 241-253. https://doi.org/10.1111/j.1439-0426.2006.00805.x

Fulton, T.W. (1902). The rate of growth of fishes, $20^{\text {th }}$ Annual Report of the Fishery Board of Scotland, (3): 326-446.

Gabr, M.H.; Bakaili, A.S and Mal, A.O. (2018). Growth, mortality and yield per recruit of the rabbit fish Siganus rivulatus (Forsskål 1775) in the red sea coast of Jeddah, Saudi Arabia, International Journal of Fisheries and Aquatic Studies, 6(1): Part B

GAFRD (2007-2016). Publications of the General Authority for Fish Resources Development. Annual fishery statistics report, Ministry of Agriculture, Egypt (In Arabic).

GAFRD (2018). Fishery statistics year book 2016, General Authority for Fish Resources Development, Ministry of Agriculture and Land Reclamation, Cairo, Egypt.

GAFRD (2019). General Authority for Fishery Resources Development, Fish Statistics Yearbooks Ministry of Agriculture and Land Reclamation, Cairo, Egypt.

Gayanilo Jr.; F.C. and Pauly, D. (1997). FAO-ICLARM fish stock assessment (FiSAT) reference manual, FAO Computerized Information Series (Fisheries), 8(2): 262pp.

George, C.J.; Athanassiou, V.A. and Boulos, I. (1964). The fishes of the coastal water of Lebanon, Misc. Pap. Nat. Sci. Am. Univ. Beirut, 4: 27.

George, C.J. (1972). Notes on the breeding and movements of the rabbitfishes Siganus rivulatus (Forsskal) and S. luridus Ruppell, in the coastal waters of Lebanon, Ann. Mus. Storia Nat. Genova, 79: 32-44.

Golani, D. (1990). Environmentally-induced meristic changes in Lessepsian fish migrants, a comparison of source and colonizing populations, Bull. Inst. Océanogr. (Monaco) Spécial Issue, 7: 143-152.

Hagras, S.A.M. (2015). Studies on Biological and Dynamics of Siganidae Family in the Bardawil Lagoon (M.Sc. Thesis), Department of Fish Resources and Aquaculture, Faculty of Environmental Agriculture Sciences, Suez Canal University, Egypt. 
Hashem, M.T. (1983). Biological studies on Siganus rivulatus (Forsk.) in the Red Sea, Journal of the Faculty of Marine Science, Jeddah 3: 119-127.

Hassan, M.; Harmelin-Vivien, M. and Bonhomme, F. (2003). Lessepsian invasion without bottleneck: example of two rabbitfish species (Siganus rivulatus and Siganus luridus), J. Exp. Mar. Biol. Ecol., 291: 219-232.

Hile, R. (1936). Age and growth of the Cisco, Leucichthys artedi (Le Sueur) in the lakes of the Northeastern high-lands. Wisconsin. Bull. Bur. Fish. U. S., 48(19): 211-317.

Htun-Han, M. (1978). The Reproductive Biology of the dab Limanda limanda (L) in the North Sea: Gonadosomatic Index, Hepatosomatic Index and Condition Factor. J. Fish. Biol, 13(1): 351-377.

King, R.P. (1996). Length-weight relationships of Nigerian freshwater fishes. Naga: The ICLARM Quarterly, 19(3): 49- 52.

King, M. (2007). Fisheries biology, assessment and management. $2^{\text {nd }}$ Edition. Blackwell Scientific Publications, Oxford, 1-381 DOI 10.1007/s10499-0079148-4

Lagler, K.F. (1956). Fresh water fishery biology. Ed. W. M. C. Browen Comp., Dubuque Iowa, 421pp.

Lam, T.J. (1974). Siganids: their biology and mariculture potential. Aquaculture, 3: 325-354.

Le Cren, E.D. (1951). The length-weight relationship and seasonal cycle in gonad weight and condition in the perch (Perca flu-viatilis). Journal of Animal Ecology, 20: 201-219.

Mohammed, N.I. (1991). Biological and biochemical studies of some siganid fishes from the Mediterranean waters off Alexandria (M.Sc. Thesis). Faculty of Science, Alexandria University.

Mouneimné, N. (1978). Poissons des côtes du Liban (méditerranée Orientale), biologie et pêche. Thèse de doctorat d' Etat ès-Sciences Naturelles. Université Pierre et Marie Curie, Paris VI, France.

Moutopoulos, D.K. and Stergiou, K.I. (2002). Length-weight and length-length relationships of fish species from Aegean Sea (Greece). Journal of Applied Ichthyology, 18: 200-203. https://doi.org/10.1046/j.1439-0426.2002.00281.x

Papaconstantinou, C. (1990). The spreading of Lessepsian fish migrants into the Aegean Sea (Greece). Sci. Mar., 54: 313-316.

Popper, D. and Gundermann, N. (1975). Some ecological and behavioral aspects of siganid populations in the Red Sea and Mediterranean coasts of Israel in relation to their suitability for aquaculture. Aquaculture, 6: 127-141.

Por, F.D. (1978). Lessepsian migration: The influx of Red Sea biota in the Mediterranean by the way of the Suez Canal. Springer Verlag, Berlin, 228pp.

Ricker, W.E. (1973). Linear regressions in fishery research. Journal of the Fisheries Research Board of Canada, 30: 409-434. 
Ricker, W.E. (1975). Computation and interpretation of biological statistics of fish populations. Bull. Fish. Res. Board Canada, 191: 382.

Saber, M.A. and Gewida, A.G.A. (2020). The influence of trammel net fishing on the Rabbit fish (Siganus rivulatus) stocks in Suez Gulf, Red Sea, Egypt. Egyptian Journal of Aquatic Biology \& Fisheries, 24(2): 135-145. DOI: $10.21608 /$ EJABF.2020.79142

Schneider, S.; Roessli, D. and Excoffier, L. (2000). Arlequin: a software for population genetics data analysis Genetics and Biometry Lab, Dept. of Anthropology, University of Geneva, Geneva.

Shakman, E.A. (2008). Lessepsian migrant fish species of the coastal waters of Libya: Status, biology, ecology (M.Sc. Thesis), Rostock University, Germany. http://rosdok.uni-

rostock.de/file/rosdok_disshab_0000000120/rosdok_derivate_0000003661/Di ssertation_Shakman_2008.pdf

Shakman, E.A.; Winkler, H.; Oeberst, R. and Kinzelbach, R. (2008). Morphometry, age and growth of Siganus luridus Rüppell, 1828 and Siganus rivulatus Forsskål, 1775 (Siganidae) in the central Mediterranean (Libyan coast). Revista de Biología Marina Oceanografía, 43(3): 521-529. DOI:10.4067/S0718-19572008000300011

Simon, K.D. and Mazlan, A.G. (2008). Length-Weight and Length-Length Relationships of Archer and Puffer Fish Species. The Open Fish Science Journal, 1: 19-22. DOI:10.2174/1874401X00801010019

Skelton, P.H. (1976). A new species of Mastacembelus (Pisces, Mastacembelidae) from the upper Zambezi River, with a discussion of the taxonomy of the genus from this system. Annals of the Cape Provincial Museums Natural History, 11(6): 103-116.

Smith, J.L.b. (1965). The sea fishes of Southern Africa. Central News Agency Ltd South Africa, 328pp.

Statgraphics. (2005). Centurion XV User Manual, 286 pp. StatPoint, Herndon.

Suresh, V.R.; Biswas, B.K.; Vinci, G.K.; Mitra, K. and Mukherjee, A. (2006). Biology and fishery of barred spiny eel, Macrognathus pancalus Hamilton. Acta Ichthyologica et Piscatoria, 36(1): 31-37. https://doi.org/10.3750/AIP2006.36.1.05

Taskavak, E. and Bilecenoglu, M. (2001). Length-weight relationship for 18 Lessepsian (Red Sea) immigrant fish species from the eastern Mediterranean coast of Turkey. J. Mar. Biol. Assoc. U. K., 18: 895-896. https://doi.org/10.1017/S0025315401004805

Tharwat, A. and Al-Owafier, M.A. (2003). Comparative study on the rabbit fishes, Siganus rivulatus, inhabit the Arabian Gulf and Siganus rivulatus inhabit the Red Sea in Saudi Arabia. Egypt. J. Aquat. Biol. \& Fish., 7 (4): 1-19. doi.10.21608/EJABF.2003.1782.HTTPS://EJABF.JOURNALS.EKB.EG/AR TICLE_1782_8E7D3DAB3F0C09A6A15CB515E5B0FA81.PDF 
Ujjania, N.C.; Kohli, M.P.S. and Sharma, L.L. (2012). Length-weight relationship and condition factors of Indian major carps (Catla catla, Labeo rohita and Cirrhinus mrigala) in Mahi Bajaj Sagar. India, Research Journal of Biology, 2(1): 30-36.

Welcom, R.L. (1979). Fisheries Ecology of Flood plain Rivers. Longman, 317pp.

Woodland, D.J. (1983). Zoogeography of the Siganidae (Pisces): an interpretation of distribution and richness patterns. Bull. Mar. Sci., 33(3): 713-717.

Wray, T. (1979). Commercial fishes of Saudi Arabia. Saudi Fisheries Company, Ministry of Agriculture and Water Resources, Saudi Arabia.

Yeldan, H. and Avsar, D. (2000). A Preliminary study on the reproduction of the rabbitfish (Siganus rivulatus (Forsskal, 1775)) in the northeastern Mediterranean. Turkish Journal of Zoology, 24: 173-182. http://journals.tubitak.gov.tr/zoology/issues/zoo-00-24-2/zoo-24-2-8-99039.pdf 